\title{
PENGEMBANGAN MAJALAH BIOLOGI SEBAGAI MEDIA PEMBELAJARAN PADA POKOKBAHASAN PROTISTA KELAS X MIA DI SMA N 7 KOTA JAMBI
}

\section{DEVELOPMENT OF BIOLOGY MAGAZINE AS A LEARNING MEDIA ON PROTIST TOPIC MATERIAL FOR X MIA CLASS IN SENIOR HIGH SCHOOL 7 JAMBI CITY}

\author{
Nurjannah Pratiwi ${ }^{1)}$, Gardjito ${ }^{2)}$, Afreni Hamidah ${ }^{2)}$ \\ e-mail:nurjannahpratiwi@ymail.com \\ Staf Pengajar Prodi Pendidikan Biologi FKIP Unja
}

\begin{abstract}
ABSTRAK Penelitian ini bertujuan untuk mengembangkan produk berupa Majalah Biologi Sebagai Media Pembelajaran. Jenis penelitian ini adalah penelitian pengembangan dengan menggunakan model pengembangan ADDIE. Subjek ujicoba dalam penelitian ini adalah 12 orang siswa untuk ujicoba kelompok kecil. Instrumen pengumpulan data diperoleh dari angket validasi ahli media pembelajaran, validasi materi, dan ujicoba kelompok kecil. Jenis data dalam penellitian ini adalah kualitatif dan kuantitatif. Data kualitatif diperoleh dari angket yang berisi tentang saran untuk perbaikan media sedangkan data kuantitatif diperoleh dari instrument angket tertutup. Hasil pengembangan produk yang sudah dikembangkan divallidasi oleh ahli media dengan persentase $78,75 \%$ dengan kategori baik dilakukan 3 kali revisi sedangkan hasil validasi ahli materi diperoleh persentase $82,5 \%$ dengan kategori sangat baik dengan 2 kali revisi. Pada ujicoba kelompok kecil dilaksanakan kepada siswa kelas X SMA N 7 Kota Jambi yang memperoleh tanggapan $81,80 \%$ yang tergolong kategori sangat baik. Berdasarkan hasil penelitian dapat disimpulkan bahwa majalah biologi sebagai media pembelajaran pada pokok bahasan protista ini layak digunakan pada proses pembelajaran.
\end{abstract}

ABSTRACT The type of the research is development research using ADDIE development model. Subject test in this research are 12 students for small group test. The instrument of data collection obtained from validation questionare from media expert, material expert, and subject small group test. Data type of this research are quatitative and qualitative. Qualitative data was obtained from questionare which containing of suggestion for media repaired, and quantitative data obtained from questionare close instrument. The result product of development validated by media expert is $78,70 \%$ include good categories with three times revision, also been validation by material expert with $82,5 \%$ very good categories with two times revision. In the small group test at Senior Highscool 7 Jambi gained the result $81,80 \%$ that classified very good categories.Based on the results Biology magazine as learning media on protist subject can be use in learning process.

Kata Kunci :Majalah Biologi, Media Pembelajaran, Protista 


\section{PENDAHULUAN}

Kemajuan media komunikasi dan informasi memberi arti tersendiri bagi kegiatan pendidikan. Teknologi informasi dan komunikasi berkembang sejalan dengan perkembangan teori yang menunjang pada kegiatan pembelajaran. Kegiatan pembelajaran merupakan kegiatan pokok dalam proses pendidikan. Pada proses pendidikan terdapat tujuan pendidikan yang harus dicapai. Pentingnya pendekatan teknologis dimaksudkan agar dapat membantu proses pendidikan dalam pencapaian tujuan pendidikan.

Tujuan pendidikan menurut implementasi Kurikulum 2013 diharapkan dapat menghasilkan insan yang produktif, kreatif, dan inovatif (Mulyasa, 2013:163). Dengan adanya pendekatan ilmiah yang sistematis dan rasional sebagaimana dituntut oleh teknologi pendidikan, tujuan pendidikan yang efektif dan efisien akan tercapai. Oleh karena itu, tidak lepas dari peran guru dalam proses pembelajaran yang menuntut kemampuan guru untuk menggunakan media sebagai salah satu bentuk penyampai informasi pada siswa.

Penggunaan media sangat membantu aktivitas proses pembelajaran di dalam maupun di luar kelas, terutama membantu peningkatan prestasi belajar siswa. Menurut Arsyad (2013:19) pemakaian media pembelajaran dalam proses belajar mengajar dapat membangkitkan keinginan dan minat yang baru, membangkitkan motivasi dan rangsangan kegiatan belajar dan bahkan membawa pengaruh psikologis terhadap siswa. Oleh karena itu, media berperan penting bagi proses pembelajaran. Salah satu bentuk media yang dapat digunakan adalah media cetak berupa majalah.

Majalah merupakan media berbasis cetak berisi konten-konten beserta gambar, dikemas secara menarik dan ditampilkan dengan sederhana agar memudahkan dalam memahami konsep.

Selain konten tersebut, majalah ini berisi informasi-informasi edukatif yang dapat menambah wawasan. Menurut Munandi (2013:100) majalah adalah media informasi dengan tugas utamanya menyampaikan berita aktual. Dalam konteks pendidikan memacu kreativitas siswa sebagai lingkungan yang kondusif dalam pembelajaran.

Hasil observasi di SMA Negeri 7 Kota Jambi bertujuan untuk mengetahui pembelajaran Biologi yang dianggap sulit oleh siswa kelas $\mathrm{X}$ dan media pembelajaran yang umumnya digunakan oleh guru pada proses pembelajaran. Media pembelajaran yang digunakan oleh guru umumnya hanya satu jenis yakni media cetak berupa buku Biologi. Sarana penunjang lain seperti komputer maupun 
internet belum tersedia, sehingga sulit untuk menampilkan gambar-gambar menarik melalui media selain buku. Karena ukuran protista yang mikroskopik, maka siswa mengalami kesulitan dalam memahami materi tersebut dan untuk dapat melihatnya hanya dapat dilakukan dengan bantuan mikroskop.

Kelemahan media yang digunakan sebelumnya yaitu media cetak berupa buku dalam menampilkan materi Protista adalah halaman yang tebal. Selain itu, siswa juga kesulitan dalam memahami konsep protista, pengklasifikasian Protista dan contoh-contoh Protista yang terdapat pada buku karena penjelasan yang terlalu panjang. Untuk mengatasi permasalahan tersebut maka diperlukan pengembangan suatu media pembelajaran yang dapat membantu siswa dalam memahami konsep dan dapat meningkatkan motivasi siswa dalam belajar sehingga dapat meningkatkan pemahaman materi.

Pengembangan sebuah media pembelajaran berupa majalah Biologi yang membantu siswa meningkatkan kemampuan dalam memahami konsep serta meningkatkan motivasi belajar siswa dalam mempelajari Protista. Majalah biologi ini diharapkan dapat membantu guru dalam menyampaikan materi dan menambah variasi media untuk mengatasi keterbatasan sarana dan prasarana penunjang berupa komputer dan internet karena berbentuk media cetak. Media pembelajaran ini sama halnya dengan media pengembangan lain yang terdapat petunjuk, indikator, evaluasi.

Kelebihan dari media yang dikembangkan ini adalah pada penyajian konten dilengkapi dengan gambar yang dibuat semenarik mungkin. Selain itu terdapat konten tambahan berupa informasi-informasi edukatif yang dapat menambah wawasan siswa, dilengkapi dengan evaluasi dalam bentuk teka-teki yang terdiri atas pertanyaan yang dijawab pada sebuah kolom. Hal ini bertujuan untuk membantu siswa memahami materi dan meningkatkan motivasi siswa setelah menggunakan majalah Biologi.

\section{METODE PENELITIAN}

Penelitian ini tergolong ke dalam penelitian dan pengembangan atau dikenal dengan Research and Development. Menurut Sugiyono (2013:407) metode penelitian dan pengembangan adalah metode penelitian yang digunakan untuk menghasilkan produk tertentu, dan menguji keefektifan produk tersebut. Selain itu menurut Setyosari (2012:214) penelitian pengembangan adalah suatu proses yang dipakai untuk mengembang- kan dan memvalidasi produk pendidikan.

Menurut Pribadi (2009:125) model desain pembelajaran ADDIE memiliki tahapan-tahapan desain sistem yang 
sederhana. Model ini sesuai dengan namanya terdiri dari lima fase atau tahap utama, yaitu (A)nalysis, (D)esain, (D)evelopment, (I)mplementation, dan (E)valuation. Adapun langkah-langkah pengembangan dalam model ADDIE ditunjukkan pada gambar berikut:

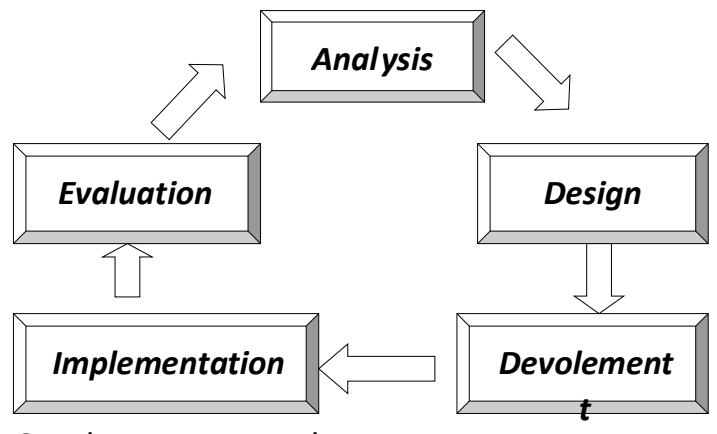

Gambar 1. Pengembangan Model ADDIE (Pribadi,2009:127).

\section{Analisis (Analysis)}

Analisis (Analysis) adalah melakukan analisis kebutuhan melalui observasi lapangan dan studi literatur. Menurut Multyaningsih (2013:200) menyatakan pada tahap ini, kegiatan utama adalah menganalisis perlunya pengembangan pada pembelajaran yang baru dan menganalisis syarat pengembangan. Berdasarkan observasi yang dilakukan di SMA N 7 Kota Jambi, SMA N 8 Kota Jambi, SMA N 10 Kota Jambi salah satu sumber belajar yang banyak digunakan adalah berupa buku yang merupakan media cetak. Pada SMA N 8 Kota Jambi dan SMA N 10 Kota Jambi penggunaan media pembelajaran berbasis sarana komputer dan prasarana internet jarang digunakan karena keterbatasan jumlah. Sedangkan pada SMA N 7 Kota Jambi penggunaan sarana dan prasarana berupa komputer dan internet tidak dapat berlangsung karena tidak tersedianya fasilitas tersebut.

Hasil wawancara dengan guru Biologi rata-rata menyatakan bahwa materi Protista merupakan materi yang sulit dipahami siswa karena kebanyakan siswa sulit membedakan antara kingdom monera dan kingdom protista. Wawancara terhadap siswa juga menyatakan bahwa materi protista sulit dipahami. Siswa sering menyatakan bahwa organisme yang tergolong kingdom protista adalah kingdom monera. Selain itu siswa mengalami kesulitan dalam memahami konsep pengklasifikasian Protista dan penggunaan istilah sulit yang banyak ditemukan. Penggunaan media pembelajaran yang kurang bervariasi dalam hal ini hanya terbatas pada buku pelajaran menjadikan motivasi membaca kurang dan kesulitan dalam memahami konsep pembelajaran.

\section{Rancangan (Design)}

Desain dan isi media disesuaikan dengan silabus Biologi SMA kelas X pada Kompetensi Dasar 1.3 dan 3.5 dengan karakteristik pembelajaran meliputi kegiatan mengamati dan menanya. 
Materi pokok meliputi ciri umum protista mirip jamur, ciri umum protista mirip tumbuhan, ciri umum protista mirip hewan yang dituangkan pada halaman cover story, sedangkan peran protista dalam kehidupan dideskripsikan dengan berita terbaru melalui halaman dampak negatif, info protista, serta alga dan teknologi. Pada halaman teka-teki protista dan tahukah kamu di bagian cover belakang diharapkan dapat menjadi informasi tambahan bagi siswa. Langkah selanjutnya adalah pengumpulan materi berdasarkan literature yang relevan dan dituangkan dalam bentuk story board yang digunakan sebagai acuan dalam pembuatan media.

\section{Pelaksanaan Pengembangan}

\section{(Development)}

Pelaksanaan pengembangan adalah langkah menghasilkan desain yang dirancang menjadi sebuah produk berupa majalah biologi. Selanjutnya produk ini divalidasi validator media dan validator materi. Validasi ini dilakukan sebelum produk diujicobakan, validasi ini dilakukan beberapa kali jika ada yang belum layak, maka dilakukan revisi hingga produk dinyatakan layak diujicoba.

\section{Implementasi (implementation)}

Tahap implementasi merupakan tahap untuk menerapkan produk yang sedang dikembangkan. Desain produk yang telah di validasi oleh validator, diujicobakan pada subjek ujicoba kelompok kecil terhadap 12 responden sebagai pemakai produk yang telah dikembangkan.

\section{Evaluasi (Evaluation)}

Evaluasi (evaluation) adalah proses untuk memperlihatkan produk yang dikembangkan berhasil dan sesuai dengan yang ditargetkan pada tahap analysis. Hasil dari evaluasi sangat berperan untuk perbaikan produk yang dikembangkan.

\section{Ujicoba Produk}

Uji coba produk yang digunakan adalah ujicoba kelompok kecil. Subjek ujicoba berjumlah 12 responden yang merupakan siswa kelas $\mathrm{X}$ di SMA $\mathrm{N} 7$ Kota Jambi.

\section{Teknik Analisis Data}

Data yang didapat dari tim ahli dalam bentuk angket dianalisis secara deskriptif dengan menggunakan skala Likert. Menurut Riduwan (2013:12) bahwa skala Likert digunakan untuk mengukur sikap, pendapat dan persepsi seseorang atau kelompok. Karena pada penelitian ini melihat sikap dan pendapat mahasiswa terhadap kamus elektronik genetika bergambar. Pertanyaan yang diajukan dalam skala Likert dinilai oleh mahsiswa dan dosen yang pernah mengampu mata kuliah genetika dengan kriteria jawaban 
sangat baik, baik, tidak baik dan sangat tidak baik Teknik analisis menggunakan rumus rata-rata untuk menghitung persentase tanggapan adalah :

$$
\%=\frac{\mathrm{F}}{\mathrm{N}} \times 100 \%
$$

Keterangan :

$\%=$ Persentase sub variabel

$\mathrm{F}=\mathrm{Jumlah}$ nilai tiap sub variabel

$\mathrm{N}=$ Jumlah skor maksimun

\section{HASIL DAN PEMBAHASAN}

\section{Penyajian Hasil Ujicoba}

$$
\text { Ujicoba pada penelitian }
$$

pengembangan ini diperoleh hasil berupa media pembelajaran berupa majalah Biologi edisi Protista untuk siswa Sekolah Menengah Atas kelas X, hasil validasi oleh ahli media dan ahli materi dalam bentuk angket, persepsi siswa terhadap media yang telah dikembangkan dengan menyebarkan angket kepada responden yaitu siswa SMA N 7 Kota Jambi kelas X yang terdiri atas 12 orang siswa sebagai subjek ujicoba kelompok kecil.

\section{Hasil Validasi Media}

Majalah Biologi sebagai media pembelajaran pada pokok bahasan protista kelas $\mathrm{X}$ yang telah dikembangkan, kemudian divalidasi oleh validator media yaitu Ir. Bambang Hariyadi, M.Si., Ph.D. Validasi oleh validator media dilakukan sebanyak tiga kali. Adapun hasil validasi media yang pertama diperoleh kategori tidak baik, validasi tahap kedua kategori baik, dan validasi tahap ketiga kategori baik.

Tabel 1. Kategori tingkat validitas media pembelajaran

\begin{tabular}{|c|c|c|}
\hline $\begin{array}{c}\text { Skala } \\
\text { Nilai }\end{array}$ & Persentase & $\begin{array}{c}\text { Instrumen } \\
\text { Jawaban }\end{array}$ \\
\hline 4 & $82 \leq$ skor $\leq 100$ & Sangat baik \\
\hline 3 & $63 \leq$ skor $\leq 81$ & Baik \\
\hline 2 & $44 \leq$ skor $\leq 62$ & Tidak baik \\
\hline 1 & $25 \leq$ skor $\leq 43$ & $\begin{array}{c}\text { Sangat tidak } \\
\text { baik }\end{array}$ \\
\hline
\end{tabular}

Riduwan (2012:89)

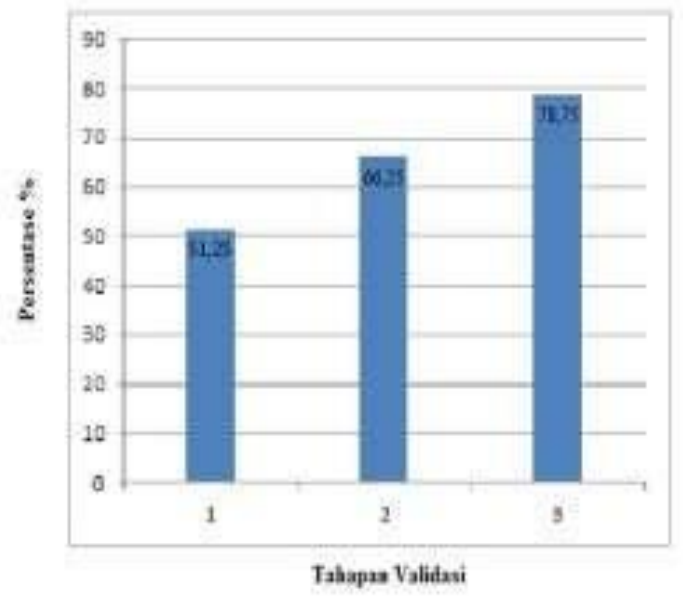

Gambar 2 Hasil Validasi media.

\section{Hasil Validasi Media}

Majalah Biologi sebagai media pembelajaran pada pokok bahasan protista kelas $\mathrm{X}$ yang telah dikembangkan, kemudian divalidasi oleh validator materi yaitu Retni.S. Budiarti, S.Pd., M.Si. Validasi oleh validator materi dilakukan sebanyak dua kali. Adapun hasil validasi 
materi yang pertama diperoleh kategori baik, validasi tahap kedua kategori sangat baik.

Tabel 2. Kategori tingkat validitas media pembelajaran

\begin{tabular}{|c|c|c|}
\hline $\begin{array}{c}\text { Skala } \\
\text { Nilai }\end{array}$ & Persentase & $\begin{array}{c}\text { Instrumen } \\
\text { Jawaban }\end{array}$ \\
\hline 4 & $82 \leq$ skor $\leq 100$ & Sangat baik \\
\hline 3 & $63 \leq$ skor $\leq 81$ & Baik \\
\hline 2 & $44 \leq$ skor $\leq 62$ & Tidak baik \\
\hline 1 & $25 \leq$ skor $\leq 43$ & $\begin{array}{c}\text { Sangat tidak } \\
\text { baik }\end{array}$ \\
\hline
\end{tabular}

Riduwan (2012:89)

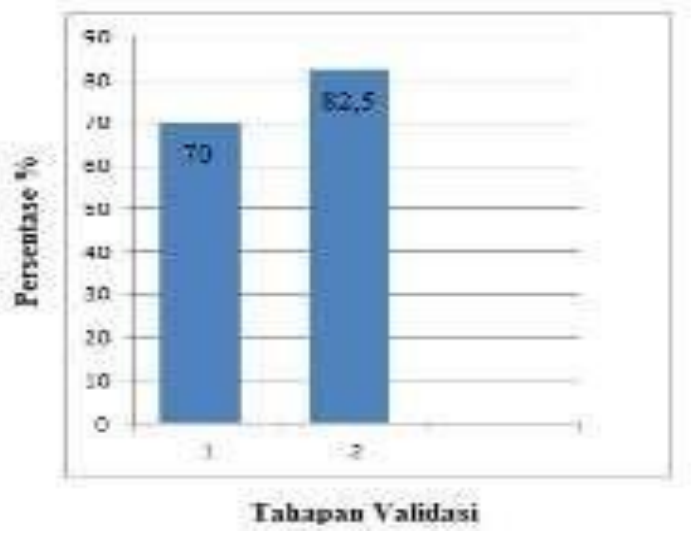

Gambar 3 Hasil Validasi media.

\section{Hasil Ujicoba Produk}

Ujicoba produk dilakukan pada kelas $\mathrm{X}$ di SMA N 7 Kota Jambi dengan jumlah responden dua belas orang. Responden diminta untuk mengisi angket persepsi dengan jumlah butir soal sebanyak 15 . Angket persepsi yang diisi oleh responden kemudian dianalisis menggunakan pengukuran skala likert.
Jumlah persentase keseluruhan yang diperoleh dari hasil ujicoba kelompok kecil pada angket persepsi adalah $81,80 \%$. Jumlah yang diperoleh menunjukkan bahwa media pembelajaran yang dikembangkan tergolong kategori "baik". Hal ini menunjukkan Majalah Biologi sebagai media pembelajaran pada pokok bahasan Protista kelas X sudah baik dan layak digunakan.

\section{KAJIAN DAN SARAN}

\section{Kajian Produk}

Kajian dari penelitian pengembangan ini adalah sebagai berikut:

1. Penelitian pengembangan ini menghasilkan produk berupa majalah Biologi sebagai media pembelajaran pada pokok bahasan protista kelas $\mathrm{X}$ di SMA N 7 Kota Jambi dengan menggunakan pengembangan ADDIE.

2. Produk yang dikembangkan kemudian divalidasi oleh ahli media dan ahli materi. Hasil validasi oleh ahli media setelah revisi sebanyak tiga kali adalah $78,75 \%$ dengan kategori baik, sedangkan hasil validasi oleh ahli materi yang dilakukan sebanyak dua kali adalah $82,5 \%$ dengan kategori baik. Kemudian produk yang telah divalidasi selanjutnya diujicobakan pada kelompok kecil. Ujicoba produk dilaksanakan di SMA N 7 Kota Jambi 
dengan jumlah responden 12 orang. Persentase tanggapan responden $81,80 \%$ dengan kategori baik.

3. Kelebihan majalah Biologi sebagai media pembelajaran pada pokok bahasan protista yaitu pertama, siswa dapat menggunakan secara langsung tanpa menggunakan perangkat komputer karena majalah Biologi ini berupa media cetak. Selain itu dapat menambah variasi media pembelajaran yang dapat menunjang proses belajar siswa secara mandiri. Kedua, secara keseluruhan media ini berisi materi pokok protista mengenai klasifikasi, ciri dan peran dalam kehidupan yang disajikan dalam bahasa yang lebih mudah dipahami dengan informasi terbaru yang berkaitan. Selain itu media dilengkapi dengan evaluasi berupa teka teki silang mengenai materi protista. Ketiga, majalah disajikan dengan tampilan penuh warna dengan penggunaan kertas kilap (glossy) agar dapat menarik minat siswa dalam membaca.

4. Kelemahan atau hambatan yang ditemukan pada waktu media dikembangkan adalah pada proses pembuatan dan desain, menggunakan lebih dari satu aplikasi komputer yaitu paint dan adobe photoshop agar menghasilkan kualitas yang baik sehingga memerlukan lebih banyak waktu.

\section{Saran Pemanfaatan}

1. Kepada peneliti selanjutnya dapat mengembangkan majalah biologi dengan pokok bahasan lainnya.

2. Produk majalah Biologi pada pokok bahasan protista dapat dijadikan media pembelajaran alternatif bagi siswa pada proses pembelajaran mandiri dengan pokok bahasan protista.

3. Sebagai bahan pembanding untuk menghasilkan media pembelajaran yang lebih baik sehingga dapat menambah ragam variasi media pembelajaran yang dapat menarik minat siswa dalam proses pembelajaran.

\section{DAFTAR RUJUKAN}

Arsyad, A. 2013. Media Pembelajaran. Jakarta: PT Raja Grafindo Persabda.

Mulyasa, E. 2013. Pengembangan dan Implementasi Kurikulum 2013. Jakarta: Rosda.

Munandi, Y. 2013. Media Pembelajaran. Jakarta: GP Press Group.

Riduwan. 2012. Belajar Mudah Penelitian untuk Guru, Karyawan, dan Peneliti Pemula. Bandung: Alfabeta.

Sugiyono. 2011. Metode Penelitian Pendidikan Pendekatan Kuantitatif, Kualitatif, dan $R$ \& D. Bandung: Alfabeta. 